
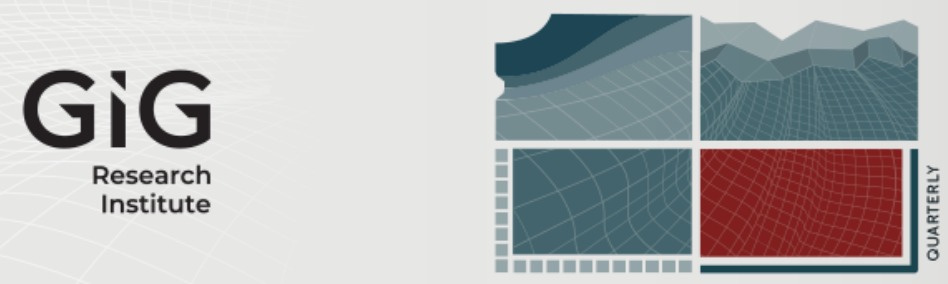

JOURNAL
OF
SUSTAINABLE
MINING

\title{
Is the relationship between mining and climate change only one- way? Climate change potential impacts on mining activity - hazards, risks and adaptation measures
}

Author(s) ORCID Identifier:

Małgorzata Markowska (iD) 0000-0002-9105-6856

Follow this and additional works at: https://jsm.gig.eu/journal-of-sustainable-mining

Part of the Explosives Engineering Commons, Oil, Gas, and Energy Commons, and the Sustainability Commons

\section{Recommended Citation}

Markowska, Małgorzata (2021) "Is the relationship between mining and climate change only one-way? Climate change potential impacts on mining activity - hazards, risks and adaptation measures," Journal of Sustainable Mining: Vol. 20 : Iss. 1 , Article 6.

Available at: https://doi.org/10.46873/2300-3960.1051

This Editorial is brought to you for free and open access by Journal of Sustainable Mining. It has been accepted for inclusion in Journal of Sustainable Mining by an authorized editor of Journal of Sustainable Mining. 
Is the relationship between mining and climate change only one-way? Climate change potential impacts on mining activity - hazards, risks and adaptation measures

Creative Commons License

(c) $(1)$

This work is licensed under a Creative Commons Attribution 4.0 License. 


\title{
Is the relationship between mining and climate change only one-way? Climate change potential impacts on mining activity - Hazards, risks and adaptation measures
}

\author{
Małgorzata Markowska
}

Central Mining Institute (Główny Instytut Górnictwa), Plac Gwarków 1, 40-166, Katowice, Poland

$I_{\mathrm{i}}^{\mathrm{t}}$ $t$ is common knowledge that the global climate is changing. Modern climate models predict rising temperatures and changes in precipitation regimes that will alter the frequency, magnitude, and geographic distribution of extreme weather events and climate-related hazards, including floods, droughts, and heatwaves.

Research into climate change and its consequences for society and economy is recognized as highly important in European Union countries and around the world. At the same time, in the case of the mining industry in Europe, the potential impacts of climate change were not an area of particular interest for many years, except for mining sector's impact on the environment including climate (e.g. through emissions). While this subject has appeared to be substantial for an operational capacity of the international mining industry, it is necessary to deepen research on extreme weather events hazards, risks and their impacts on mining activity.

For many years, research focused on the fact that climate change and its consequences can significantly affect the operations of the mining industry, was carried out mostly in Canada and Australia, due to the specifics of the geographical location and mining activities in these areas. Only recently has it also become an object of interest for European researchers.
At present, the issue of climate change and its impact on the activities of the mining industry is becoming increasingly important for the safety of mining regions, also because the European mining industry is in a period of transition, already cutting costs and mining coal and implementing environmentally friendly solutions to meet the requirements of the European Green Deal and the EU's commitment to reduce $\mathrm{CO}_{2}$ emissions in 2050 perspective.

One of the research works undergoing is TEXMIN project, focused on assessing and minimising the environmental impact of extreme weather events on the mining operations, implemented within Research Fund for Coal and Steel (RFCS).

Selected articles are presented in the virtual special issue of the Journal of Sustainable Mining. These articles illustrate the various aspects and approaches for climate change impact on mining industry, as well as different measures being undertaken to increase stability and safety of mining activities despite progressing climate change and related hazards. As an international group of researchers in TEXMIN consortium from Poland, Czech Republic, Germany, Greece, Spain and the United Kingdom, we hope, that this issue will start a fruitful discussion of such problems on the pages of the Journal of Sustainable Mining. 